\title{
Characteristics of a COVID-19 confirmed case series in primary care (COVID-19-PC project): a cross-sectional study
}

\author{
Eloisa Rogero-Blanco 1,2 ${ }^{1}$ Vera González-García³, Rodrigo Medina García' , Pilar Muñoz-Molina³, \\ Santiago Machin-Hamalainen ${ }^{{ }^{*}}$, Juan A. López-Rodríguez ${ }^{1,2,4,5}$ and Grupo COVID-AP1,3,6
}

\begin{abstract}
Background: To estimate the prevalence of symptoms and signs related to a COVID-19 case series confirmed by polymerase chain reaction (PCR) for SARS-CoV-2. Risk factors and the associated use of health services will also be analysed.

Methods: Observational, descriptive, retrospective case series study. The study was performed at two Primary Care Health Centres located in Madrid, Spain. The subjects studied were all PCR SARS-CoV-2 confirmed cases older than 18 years, diagnosed from the beginning of the community transmission (March 13) until April 15, 2020. We collected sociodemographic, clinical, health service utilization and clinical course variables during the following months. All data was gathered by their own attending physician, and electronic medical records were reviewed individually. Statistical analysis: A descriptive analysis was carried out and a Poisson regression model was adjusted to study associated factors to Health Services use.
\end{abstract}

Results: Out of the 499 patients studied from two health centres, 55.1\% were women and mean age was 58.2 (17.3). 25.1\% were healthcare professionals. The most frequent symptoms recorded related to COVID-19 were cough (77.9\%; Cl 95\% 46.5-93.4), fever (77.7\%; C195\% 46.5-93.4) and dyspnoea (54.1\%, C195\% 46.6-61.4). 60.7\% were admitted to hospital. $64.5 \%$ first established contact with their primary care provider before going to the hospital, with a mean number of 11.4 Healthcare Providers Encounters with primary care during all the follow-up period.

The number of visit-encounters with primary care was associated with being male [IRR 1.072 (1.013, 1.134)], disease severity \{from mild respiratory infection [IRR $1.404(1.095,1.801)]$, up to bilateral pneumonia [IRR 1.852 (1.437,2.386)]\}, and the need of a work leave [IRR $1.326(1.244,1.413]$.

Conclusion: Symptoms and risk factors in our case series are similar to those in other studies. There was a high number of patients with atypical unilateral or bilateral pneumonia. Care for COVID has required a high use of healthcare resources such as clinical encounters and work leaves.

Keywords: COVID-19 [Supplementary Concept], Coronavirus Infections, Pneumonia, Viral, Primary Health Care

*Correspondence: santimach@gmail.com

1 Primary Health Care Centre General Ricardos, Calle General Ricardos 131, 28019 Madrid, Spain

Full list of author information is available at the end of the article give appropriate credit to the original author(s) and the source, provide a link to the Creative Commons licence, and indicate if changes were made. The images or other third party material in this article are included in the article's Creative Commons licence, unless indicated otherwise in a credit line to the material. If material is not included in the article's Creative Commons licence and your intended use is not permitted by statutory regulation or exceeds the permitted use, you will need to obtain permission directly from the copyright holder. To view a copy of this licence, visit http://creativecommons.org/licenses/by/4.0/. The Creative Commons Public Domain Dedication waiver (http://creativecommons.org/publicdomain/zero/1.0/) applies to the data made available in this article, unless otherwise stated in a credit line to the data. 


\section{Background}

As of December 31, 2019, the Chinese Authorities communicated to the WHO some pneumonia cases of unknown aetiology at Wuhan. A week later the Authorities confirmed it was caused by the new coronavirus called SARS-CoV-2 [1] (Severe Acute Respiratory Syndrome CoronaVirus 2).

In Spain, the first cases gradually began to appear since January 31 with a peak on March $20^{\text {th }}$ [2]. At the beginning of July 2020, the number of confirmed cases with a polymerase chain reaction (PCR) in Spain was over 251,000, and worldwide over 11 million cases [3]. In the Spanish National Seroprevalence Study (ENECOVID) [4] a 5\% prevalence was detected with rapid point of care antibody test and a $4.6 \%$ prevalence with the immunoassay test.

The symptoms associated with this viral infection have been called COVID-19 (Coronavirus Disease) and it includes respiratory symptoms such as a common cold, severe pneumonia, up to respiratory distress syndrome, septic shock and multiorgan failure. Initially, PCR test was not universally performed in those COVID-19 symptomatic patients.

From the clinical point of view, the most important published COVID-19 case series have been described in inpatients samples [5-7]. So far, there have been few published studies describing Primary Care (PC) case series [8]. The published studies reflect the disease semiology, as well as the main alterations of the complementary tests, risk factors, different treatments used and the disease evolution. With the RENAVE (National Epidemiological Surveillance Network) available data, the most frequent symptoms in PCR confirmed cases $(n=248,329)$ [9] were: fever or having had fever recently $(72.9 \%)$, cough $(69.0 \%)$, dyspnoea $(47.6 \%)$ and diarrhoea (26.8\%). But the real incidence of the clinical symptoms associated with the SARS-CoV-2 infection is unknown. In the report "COVID-19 Atención Primaria" [10] made by the Madrid Public Health System, in the Autonomous Community of Madrid 323,583 patients were attended in the PC Practices with COVID-19 confirmed or suspected. Out of those, only 52,902 (16.35\%) were PCR confirmed; $53.8 \%$ of the PCR confirmed cases were diagnosed either of radiological or clinical pneumonia.

Since the change of epidemiological context and following the Spanish Ministry of Health instructions, mild COVID-19 cases should be diagnosed, followed up and epidemiologically surveilled at $\mathrm{PC}$ in coordination with the Public Health Care Services [11]. To perform those duties, $\mathrm{PC}$ had to reorganize its activities in order to lower the risk of contagion associated with crowds in closed facilities and prioritize emergency care and isolation of suspected cases [12]. To that effect, circuits inside the Health Centres had to be created to divide COVID-19 suspected cases assistance from other pathologies and, also, to prioritize telephone medical consults as well as home assistance.

In the Madrid region, 9.8\% of the patients followed by PC since they had their first symptoms needed admission as inpatients. From the onset of symptoms, it took an average of 7.8 days to be admitted as inpatients [9]. Early detection of disease worsening of COVID-19 patients has been a priority for $\mathrm{PC}$ and it has been mainly done with follow-up phone consultations. So far there are no studies that analyse the socio demographic characteristics, symptoms, evolution and use of PC resources in Spain in this pandemic scenario.

The main objective of this study is to estimate the prevalence of symptoms and signs related to the COVID-19 infection confirmed by a PCR test for SARS-CoV-2, in patients older than 18 years in PC in the South Area of Madrid. Also, the risk factors and the use of healthcare resources associated with the COVID-19 infection will be analysed.

\section{Methods}

Observational, descriptive, retrospective, followed-up case series study at two Primary Care Health Care Centres in the south area of Madrid.

Eligibility criteria were: a) older than 18 years b) having their attending Family Physician notified as PCR positive by the Official Public Health notification system c) being followed up (either by phone interviews or at the office) by their attending physician/nurse d) verbal informed consent to participate in the COVID-AP study. Exclusion criteria were: a) Institutionalized patients that were followed up by other sanitary professionals b) Those with mental disabilities or disorders whom their attending physicians judged couldn't follow up the study requirements.

All cases that were notified in the electronical medical record (EMR) until the 15 of April 2020, by the Madrid Public Health Alert system, were analysed. Therefore, the sample was taken in a consecutive way as the cases were being notified from the referral hospitals and the Public Health Services to the attending physicians. The patients were followed up for 30 days after the positive PCR test was done. The data was gathered from May 16th until June 15th when the follow up period was over. 58 Family Physicians participated in the study and a total of 525 patients were confirmed and notified as PCR positive. Given a $11.5 \%$ of infected population estimation in the Madrid Autonomous Region, assuming the worst-case scenario for some symptoms (50\%), and given a $95 \%$ confidence interval, the precision needed would be $4.27 \%$. 


\section{Variables}

Main variables were symptoms related to the infection (fever, cough, odynophagia, dyspnoea, chills, vomits, diarrhoea, and anosmia/hyposmia) described in the patient's EMR throught all the follow up period disregarding the moment in which they appeared. Secondary variables were: 1 . Sociodemographic: age, gender, nationality (Spanish/ Non-Spanish), being a healthcare professional 2. Patient's comorbidities: high blood pressure (HBP), chronic obstructive pulmonary disease (COPD), asthma, diabetes, ischemic heart disease, cerebrovascular disease, chronic kidney disease, hepatic failure, immunosuppression, oncologic disease in the previous 5 years 3 . Disease progression: first day with symptoms, first medical consultation date, positive COVID-19 test date, having been diagnosed of clinical pneumonia or radiologic pneumonia (unilateral or bilateral), 4. Use of resources: Primary Care contact before the PCR test, type of consult (phone, office), number of healthcare provider encounters (HPE) performed (before, during and after hospital care if needed), house calls made, need of hospital care at the Emergency Department, admitted as hospital inpatient, date of admission, date of discharge, place to be discharged, number of phone follow-ups after discharge, need of work leave and how many days of work leave were needed.

Family physicians collected the information from the patients' EMR and their hospital discharge reports. Afterwards, they registered it anonymously into an online Data Collection Questionnaire (https://covidap. es/) with a random identification number. The data was gathered from May 16th until June 15th when the follow up period was over.

\section{Statistical analysis}

The categorical variables were described as frequency and percentage; quantitative variables as average and standard deviation with a $95 \%$ confidence interval if they followed a normal distribution. In asymmetrical distributions, or not normal, the median and interquartile range were reported. The prevalence of the main symptoms detected were estimated with a $95 \%$ confidence interval. Bivariate analysis was done by groups (needing hospital care/not needing) using Chi square test for categorical variables and a Student's T-test (or a Mann- Whitney U if the distribution was not normal) in the quantitative test. Multivariate Poisson regression model was adjusted to analyse associated factors being the number or HPE the dependant variable. All statistical analyses were performed using a standard software package (Stata, version 14.0).

All methods were carried out in accordance with relevant guidelines and regulations. Informed consent was obtained from all the participants.

\section{Results}

Out of the 525 patients that had a SARS- Cov-2 PCR confirmed infection, that was notified to their primary care physician, 499 were analysed (Fig. 1).

Out of these 499 patients: 275 (55.1\%) were women, their average age was 58.2 years old (SD17.3) and 125 (25.1\%) were healthcare workers. Most frequent risk factors were HBP (32.9\%) and diabetes (17.5\%). Table 1 summarizes the patients sociodemographic characteristics and risk factors.

Out of the 499 analysed patients, 488 (97.8\%) had some symptom. Most frequent symptoms referred by the patients along the infection were: cough (78.0\%; CI95\%

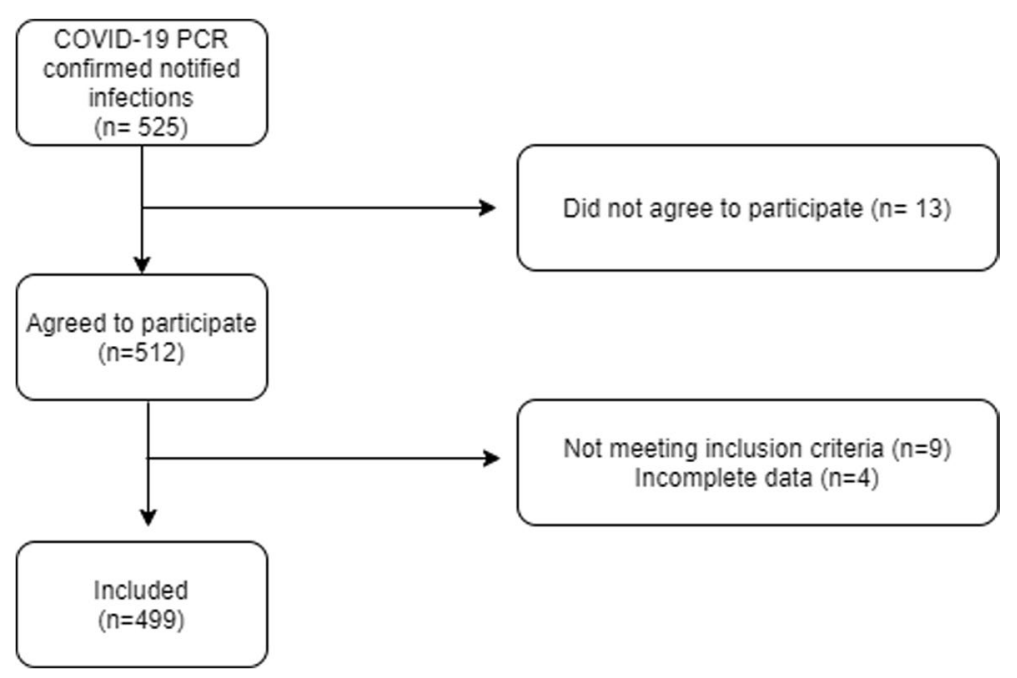

Fig. 1 Patients included in the study 
Table 1 Sociodemographic characteristics, and risk factors of patients according to gender

\begin{tabular}{|c|c|c|c|c|}
\hline & Total & Men & Women & $p$ value \\
\hline & 499 & $224(44.9 \%)$ & $275(55.1 \%)$ & \\
\hline Age, mean (SD) & $58.2(17.3)$ & $61.1(17.2)$ & $55.7(17.1)$ & $<0.001^{*}$ \\
\hline 10 years age categories n(\%) & & & & 0.003 \\
\hline 18-25 years & $15(3.0 \%)$ & $2(0.9 \%)$ & $13(4.7 \%)$ & Ref. $^{\$}$ \\
\hline $26-35$ years & $38(7.6 \%)$ & $15(6.7 \%)$ & $23(8.4 \%)$ & 0.081 \\
\hline $36-45$ years & $68(13.6 \%)$ & $28(12.5 \%)$ & $40(14.5 \%)$ & 0.058 \\
\hline $46-55$ years & $117(23.4 \%)$ & $45(20.1 \%)$ & $72(26.2 \%)$ & 0.073 \\
\hline $56-65$ years & $96(19.2 \%)$ & $38(17.0 \%)$ & $58(21.1 \%)$ & 0.066 \\
\hline $66-75$ years & $69(13.8 \%)$ & $41(18.3 \%)$ & $28(10.2 \%)$ & 0.005 \\
\hline $76-85$ years & $69(13.8 \%)$ & $40(17.9 \%)$ & $29(10.5 \%)$ & 0.006 \\
\hline$>85$ years & $27(5.4 \%)$ & $15(6.7 \%)$ & $12(4.4 \%)$ & 0.014 \\
\hline Country of origin & & & & 0.68 \\
\hline Spain & $327(65.5 \%)$ & $147(65.6 \%)$ & $180(65.5 \%)$ & \\
\hline Others & $145(29.1 \%)$ & $67(29.9 \%)$ & $78(28.4 \%)$ & \\
\hline $\mathrm{NR} / \mathrm{DK}^{*}$ & $27(5.4 \%)$ & $10(4.5 \%)$ & $17(6.2 \%)$ & \\
\hline BMl, mean (SD) & $28.5(4.9)$ & $28.7(4.5)$ & $28.4(5.1)$ & $0.53^{*}$ \\
\hline Registered as smoker in the EMR & $33(7.8 \%)$ & $22(11.5 \%)$ & $11(4.8 \%)$ & 0.011 \\
\hline Healthcare provider n(\%) & $125(25.1 \%)$ & $21(9.4 \%)$ & $104(37.8 \%)$ & $<0.001$ \\
\hline $\mathrm{HBP}$ & $164(32.9 \%)$ & $91(40.8 \%)$ & $73(26.5 \%)$ & $<0.001$ \\
\hline Diabetes & $87(17.5 \%)$ & $49(22.0 \%)$ & $38(13.8 \%)$ & 0.017 \\
\hline Asthma & $36(7.2 \%)$ & $9(4.0 \%)$ & $27(9.9 \%)$ & 0.013 \\
\hline CAD & $24(4.8 \%)$ & $21(9.4 \%)$ & $3(1.1 \%)$ & $<0.001$ \\
\hline Cerebrovascular disease & $19(3.8 \%)$ & $16(7.2 \%)$ & $3(1.1 \%)$ & $<0.001$ \\
\hline COPD & $24(4.8 \%)$ & $20(9.0 \%)$ & $4(1.5 \%)$ & $<0.001$ \\
\hline CKD & $27(5.4 \%)$ & $16(7.2 \%)$ & $11(4.0 \%)$ & 0.12 \\
\hline Oncologic disease (in the last 5yrs) & $40(8.0 \%)$ & $19(8.5 \%)$ & $21(7.6 \%)$ & 0.72 \\
\hline
\end{tabular}

*NR/DK: Not response/doesn't know; EMR Electronic Medical Record, HBP High Blood Pressure, CAD Coronary Artery Disease, COPD Chronic Obstructive Pulmonary Disease, CKD Chronic Kidney Disease, All analyses are Chi-Square test unless opposite specified; $¥$ Student $\mathrm{T}$ test; $\$$ Logistic univariate with reference category

46.5-93.4), fever (77.8\%; CI95\% 46.5-93.4) and dyspnoea (54.1\%; CI95\% 46.6-61.4). Anosmia (15.0\%; CI95\% 13.7-16.4) and ageusia /hypogeusia were less frequent (13.8\%; CI95\% 10.4-18.2). Among the main COVID-19 clinical diagnosis we found bilateral or severe pneumonia $(45.5 \%)$ and mild respiratory infections (24.0\%). 37 (7.4\%) patients died, one of them at home. All symptoms analysed and main patients' diagnoses are shown in Table 2. 392 (78.6\%) patients required hospital care, and $303(60.7 \%)$ needed to be admitted as inpatients. Mean time from the beginning of the symptoms until the hospital admission as inpatient were 7.8 days (SD 5.2). Median time of hospital admission was 8 days (interquartile range from 5 to 14). 29 (9.3\%) patients were admitted to the Critical Care Unit.

Regarding the use of PC resources: 16 of April, 2020 was the date in which the highest number of first contacts was made with PC; 322 patients (64.5\%) consulted PC prior to having a PCR for the first time. The average number of HPE in PC (with all the healthcare providers: physicians and nurses, and modalities: phone call or office visit, emergency or programmed visit) was 11.4 (6.8), during the next 30 days after the infection was confirmed; 53 patients $(10.6 \%)$ needed home visits; 237 patients $(75 \%)$ had instructions to be followed up in PC after being discharged; 225 patients (45.5\%) needed a work leave certificate, which lasted an average of 31.8 days (SD15.4). In Table 3 a description of the $\mathrm{PC}$ resources used in the population according to needing hospital care or not.

Among the factors associated with the increase of HPE were: being male [IRR 1.072; CI95\% 1.013, 1.134], mild respiratory infection [IRR 1.404; CI95\% 1.095, 1.801], moderate respiratory infection [IRR 1.802; CI95\% 1.372, 2.369], unilateral pneumonia [IRR 1.895; CI95\% 1.467, 2.447], bilateral pneumonia [IRR 1.852; CI95\% 1.437,2.386], respiratory distress syndrome [IRR 1.404; CI95\% 1.055, 1.868)] and the need of a work leave [IRR 1.326; CI95\% 1.244, 1.413]. Cerebrovascular disease was associated with less HCE [IRR 0.700; CI95\% 0.590, 0.829)]. Univariate analysis and multivariate analysis can be found in Table 4. 
Table 2 Main symptoms referred during the disease and final diagnosis according to the need of being treated at the hospital or not

\begin{tabular}{|c|c|c|c|c|c|}
\hline & Total $(n=499)$ & $\%(\mathrm{Cl} 95 \%)$ & $\begin{array}{l}\text { Need of Hospital } \\
\text { care }^{a}(n=392)\end{array}$ & $\begin{array}{l}\text { Didn't require Hospital } \\
\text { Care }(n=107)\end{array}$ & $p$ value \\
\hline \multicolumn{6}{|l|}{ Main Symptoms n(\%) } \\
\hline Anosmia & 75 & $15.03(13.7-16.4)$ & $46(12.8)$ & $29(29.6)$ & $<0.001$ \\
\hline Arthralgia/Myalgia & 224 & $44.89(5.7-91.6)$ & $182(50.3)$ & $42(42.0)$ & 0.14 \\
\hline Asthenia & 222 & $44.49(27.9-62.4)$ & $188(51.8)$ & $34(34.3)$ & 0.002 \\
\hline Diarrhoea & 135 & $27.05(11-52.8)$ & $116(32.0)$ & $19(19.2)$ & 0.013 \\
\hline Dyspnoea & 270 & $54.11(46.6-61.4)$ & $245(65.0)$ & $25(25.5)$ & $<0.001$ \\
\hline Chills & 155 & $31.06(9-67.3)$ & $139(38.7)$ & $16(16.7)$ & $<0.001$ \\
\hline Fever & 388 & $77.76(46.5-93.4)$ & $331(88.0)$ & $57(56.4)$ & $<0.001$ \\
\hline Hypogeusia & 69 & $13.83(10.4-18.2)$ & $43(12.0)$ & $26(26.5)$ & $<0.001$ \\
\hline Nausea Nomiting & 70 & $14.03(4.1-38.4)$ & $62(17.4)$ & $8(8.1)$ & 0.023 \\
\hline Odynophagia & 126 & $25.25(14.8-39.7)$ & $89(24.9)$ & $37(37.0)$ & 0.016 \\
\hline Skin reactions & 18 & $3.61(0.1-59.4)$ & $13(3.6)$ & $5(5.1)$ & 0.51 \\
\hline Cough & 389 & $77.96(46.5-93.4)$ & $314(84.0)$ & $75(75.0)$ & 0.038 \\
\hline \multicolumn{6}{|l|}{ Final Diagnosis n(\%) } \\
\hline Asymptomatic case & $9(1.8)$ & & $4(1.0)$ & $5(4.7)$ & $<0.001$ \\
\hline Mild respiratory disease & $120(24)$ & & $22(5.8)$ & 98 (91.6) & \\
\hline Moderate respiratory disease & $48(9.6)$ & & $46(12.0)$ & $2(1.9)$ & \\
\hline Non severe or unilateral Pneumonia & $62(12.4)$ & & $61(16.0)$ & $1(0.9)$ & \\
\hline Bilateral Pneumonia & $227(45.5)$ & & $226(59.2)$ & $1(0.9)$ & \\
\hline Acute Respiratory Distress & $23(4.6)$ & & $23(6.0)$ & $0(0.0)$ & \\
\hline Deceased $n(\%)$ & $37(7.4)$ & & $36(9.2)$ & $1(0.9)$ & $<0.001$ \\
\hline
\end{tabular}

${ }^{a}$ Need of hospital care: includes Emergency Department and hospital inpatients

\section{Discussion}

Out of a total of 499 patients studied from 2 different PC Health Centres at Madrid, the most prevalent symptoms associated to COVID19 infection were cough, fever and dyspnoea. HBP and diabetes were the most frequent risk factors. $25 \%$ of the patients were healthcare professionals. $60.7 \%$ required hospital admission as inpatients. $64.5 \%$ of patients had their first contact with a health care provider at PC. The average number of follow up contacts with PC was 11.4. The first contact with PC was mostly made by phone call. A work leave was needed by $45.5 \%$ patients with an average duration of 31.8 days.

Table 3 Use of Primary Care resources according to the need of being treated at the hospital or not

\begin{tabular}{|c|c|c|c|c|}
\hline & Total $(n=499)$ & $\begin{array}{l}\text { Need of Hospital Care } \\
(n=392)\end{array}$ & $\begin{array}{l}\text { Didn't require Hospital } \\
\text { Care }(n=107)\end{array}$ & $p$ value \\
\hline Mean appointments ${ }^{\mathrm{a}}$ with $\mathrm{PC} \times(\mathrm{SD})$ & $11.4(6.8)$ & $11.6(6.6)$ & 0.21 & 0.21 \\
\hline Type of appointment the first-time n(\%) & & & & 0.004 \\
\hline Phone Call & $274(59.8 \%)$ & $202(56.3 \%)$ & $72(72.7 \%)$ & \\
\hline GP Surgery visit & $184(40.2 \%)$ & $157(43.7 \%)$ & $27(27.6 \%)$ & \\
\hline Need of Housecall n(\%) & $53(10.8 \%)$ & $51(13.2 \%)$ & $2(1.9 \%)$ & $<0.001$ \\
\hline $\begin{array}{l}\text { Asked to visit the surgery during follow-up } \\
\mathrm{n}(\%)\end{array}$ & $124(25.6 \%)$ & $104(27.6 \%)$ & $20(18.7 \%)$ & 0.063 \\
\hline Chest $X$-ray requested in $\mathrm{PC} n(\%)$ & $104(21.1 \%)$ & $94(24.3 \%)$ & $10(9.3 \%)$ & $<0.001$ \\
\hline Blood test requested in $\mathrm{PC}, \mathrm{n}(\%)$ & $15(3.0 \%)$ & $11(2.8 \%)$ & $4(3.7 \%)$ & 0.75 \\
\hline Follow-up PCR requested in PC, n(\%) & $87(17.8 \%)$ & $48(12.6 \%)$ & $39(36.4 \%)$ & $<0.001$ \\
\hline Mean appointments after hospital discharge & & $6.1(4.0)$ & & \\
\hline Work Leave needed, n(\%) & $225(45.5 \%)$ & $132(34.0 \%)$ & $93(86.9 \%)$ & $<0.001$ \\
\hline Mean days of Work Leave, x(SD) & $31.8(15.4)$ & $36.7(16.5)$ & $25.9(11.6)$ & $<0.001$ \\
\hline
\end{tabular}


Table 4 Associated factor related with the number of Healthcare Provider Encounters in PC

\begin{tabular}{|c|c|c|c|c|}
\hline & \multicolumn{2}{|c|}{ Univariate } & \multicolumn{2}{|c|}{ Multivariate } \\
\hline & IRR & $\mathrm{Cl} 95 \%$ & IRR* & $\mathrm{Cl} 95 \%$ \\
\hline Age & $0.998^{*}$ & {$[0.997,1.000]$} & 1.001 & {$[0.999,1.003]$} \\
\hline Sex (Male) & 1.042 & {$[0.988,1.098]$} & $1.072^{*}$ & {$[1.013,1.134]$} \\
\hline Body Mass Index & 1.006 & {$[1.000,1.012]$} & & \\
\hline Smoking history + & 0.915 & {$[0.821,1.019]$} & & \\
\hline High Blood Pressure+ & 0.963 & {$[0.911,1.018]$} & & \\
\hline Chronic Obstructive Pulmonary Disease & $0.794^{* * *}$ & {$[0.694,0.909]$} & & \\
\hline Asthma & $1.272^{* * *}$ & {$[1.159,1.396]$} & & \\
\hline Diabetes & 0.961 & {$[0.896,1.030]$} & & \\
\hline Ischaemic Heart Disease & 0.901 & {$[0.792,1.026]$} & & \\
\hline Cerebrovascular Disease & $0.654^{* * *}$ & {$[0.555,0.772]$} & $0.700^{* * *}$ & {$[0.590,0.829]$} \\
\hline Oncological disease & $0.894^{*}$ & {$[0.808,0.990]$} & & \\
\hline Chronic Kidney Disease & 0.918 & {$[0.813,1.037]$} & & \\
\hline Needing Hospital Care & $1.088^{*}$ & {$[1.020,1.161]$} & & \\
\hline Being Hospitalized as inpatient & $0.895^{* *}$ & {$[0.832,0.964]$} & 0.968 & {$[0.893,1.049]$} \\
\hline \multicolumn{5}{|l|}{ Final Diagnosis } \\
\hline Asymptomatic & ref & & Ref & \\
\hline Mild Respiratory infection & $1.490^{* *}$ & {$[1.163,1.910]$} & $1.404^{* *}$ & {$[1.095,1.801]$} \\
\hline Moderate Respiratory infection & $1.592^{* * *}$ & {$[1.215,2.086]$} & $1.802^{* * *}$ & {$[1.372,2.369]$} \\
\hline Unilateral Pneumonia & $1.802^{* * *}$ & {$[1.400,2.319]$} & $1.895^{* * *}$ & {$[1.467,2.447]$} \\
\hline Bilateral & $1.646^{* * *}$ & {$[1.287,2.105]$} & $1.852^{* * *}$ & {$[1.437,2.386]$} \\
\hline Respiratory Distress Syndrome & 1.246 & {$[0.943,1.647]$} & $1.404^{*}$ & {$[1.055,1.868]$} \\
\hline Work leave needed & $1.254^{* * *}$ & {$[1.190,1.321]$} & $1.326^{* * *}$ & {$[1.244,1.413]$} \\
\hline
\end{tabular}

Exponentiated coefficients; 95\% confidence intervals in brackets; Multivariate Adjusted Poisson Regression Model

+ Not having means reference category

Goodness of fit: AIC 3882.3, BIC 3928.4

${ }^{*} p<0.05,{ }^{* *} p<0.01,{ }^{* * *} p<0.001$

Age and gender distribution in this case series is similar to previous studies [5-10, 13-15], although most of the other studies were made at hospital facilities. We have found only two other studies that used data from PC settings $[8,16,17]$. Most frequent symptoms were fever, cough and dyspnoea which coincide with most studies and official reports. In our study some symptoms, such as dyspnoea and cough, have higher prevalence. This fact could be explained due to the way the study was performed, in which while reviewing the clinical histories those symptoms were searched exhaustively from the very beginning to the end of the follow-up. Anosmia and ageusia were present in $15 \%$ and $13.8 \%$ of the patients of our study. These symptoms were first described in April 2020 , with different prevalence according to the case series $[18,19]$.

Almost all of our patients were symptomatic and more than half of them had pneumonia (unilateral or bilateral). These results are above the ones given in the RENAVE COVID19[9] report and this difference could be explained by the way the sample was taken. In Spain at the beginning of the pandemic, only healthcare providers and the severe infections had a PCR test indicated and those tests were only performed at Hospital facilities. The same occurred to the hospitalization rates. The official guidelines to PCR test changed according to their availability and the community transmission status [20]. Since the data from the onset of the pandemic included only the PCR confirmed infections, some of the mild cases were not included in our study. Since May 2020, a PCR confirmation test was indicated for all clinical cases regardless of the severity of their symptoms or the health care provider (Hospital or Primary Care facilities) [11].

The use of PC resources has scarcely been studied at all. There are studies that highlight the PC attention as a main player in the pandemic and its fast adaptation to the new assistance model: prioritizing phone call consults and creating separated paths to treat patients with covid19 infection (confirmed or suspected) from nonCOVID patients [21-27]. However, the burden it has meant to the healthcare providers and its costs have not been studied in detail. In our study, 64.5\% of COVID19 
patients contacted for the first time with $\mathrm{PC}$, which supports the importance of $\mathrm{PC}$ in early detection. Also, the average number of 11.4 follow up contacts in the first months in those patients support the importance of Primary Care in containing of a pandemic.

The high percentage of patients (45.5\%) needing a work leave increased the bureaucracy burden indeed and paperwork in the peak of the pandemic. Even the National Social Security Institute modified its procedures to facilitate patients' confinement and communications with the companies the patients worked in. This increase in bureaucracy has also been described by other authors [28].

Among the factors associated with increasing the number of HPE we found disease severity and the need of a work leave. Even after adjusting with multivariate regression, they remained of statistical significance and some other important covariates that could be expected to influence that, such us respiratory diseases, dropped from the model. Also being male and having cerebrovascular disease were associated with the number of HPE and no explanation for that could be hypothesized. Further studies are needed and another HPE measurement at 6 or 12 months could be of help in that.

SaRS-CoV-2 has caused the first pandemic for a coronavirus, taking the health systems of different countries at the verge of collapse, and causing the closure of many institutions. The reorganization of the Health Systems to cope with this pandemic could lead us to an unequal distribution of the health resources, prioritizing medical treatment exclusively for COVID19 patients and unable to cope with other common acute and chronic conditions usually followed by PC.

\section{Strengths and weaknesses}

On the one hand, one of the strongest points of our study was that the electronic medical record was reviewed exhaustively by their own family physician, who already knew the patient and frequently was in charge in most of the patient follow up. Also, the patients were followed up for 30 days after the positive PCR test was done. We do consider 30 days to be a longer follow up than other studies.

On the other hand, one limitation of this study was that since the data from the onset of the pandemic included only the PCR confirmed infections, some of the mild cases were not included in our study.

Other shortcoming could be that in the follow up we didn't register when each new symptom appeared, therefore we can't correlate the symptoms with the disease evolution.

\section{Conclusion}

Symptoms and risk factors found in our case series in the South area of Madrid are similar to previous studies. The rate of unilateral or bilateral pneumonia in the confirmed cases was high. COVID-19 healthcare attention required the use of an elevated number of sociosanitary resources. The health care system has been posed to its limits due to phone/office emergency and follow up consults, as well as time spent by physicians with work leaves, and other paperwork for COVID19 patients, above the average Primary Care practices. Later, broader cost studies will be needed to quantify the impact in the health system.

\section{Abbreviations}

PCR: Polymerase Chain Reaction; COVID: Coronavirus Disease; PC: Primary Care; EMR: Electronical Medical Record; HPE: Healthcare Providers Encounters; HBP: High Blood Pressure; COPD: Chronic Obstructive Pulmonary Disease.

\section{Acknowledgements \\ Grupo COVID-AP}

Primary Health Care Centre General Ricardos: Francisco Abellán-López,

Marta Barranco-Apoita, Carlos Bernaldo-de-Quirós, Manuel M Bernaldo-Corral, Marta Bosom-Velasco, Carlos Casado-Álvaro, Pilar Casado-Sanz, Pilar ChavesSánchez, Paulino Cubero-González, Eva de-la-Torre-Buedo, Patricia DocavoMuñiz, Raquel Fernández-Díaz, Teresa Ferrer-Valeiras, José D Garcés-Ranz, Celeste García-Galeano, Jorge Gómez-Ciriano, Soledad Gómez-Criado, Marta Herranz-López, Josefina Hontanilla-Calatayud, Jorge Hurtado-Gallar, Pablo Jerez-Fernández, Juan A López-Rodríguez, Santiago Machín-Hamalainen, Jacinto Macías-Rodríguez, Teresa Marín-Becerra, Raquel Mateo-Fernández, Rodrigo Medina-García, Paz Moldes-Rodríguez, Sara Morcillo-Cebolla, Purificación Pajares-Box, Lydia Palacios-Goncalves, Guilherme A Preto-Berdeja, Asunción Prieto-Orzanco, Lara Quintana-Arencibia, Elosia Rogero-Blanco, Tomás Rossignoli-Fernández, María J San-Telesforo-Navarro, Sara SánchezBarreiro, Laura Santos-Franco, Clara Vila-I-Torello, Teresa Ferrer-Valeiras. Primary Health Care Centre Los Rosales: Ana Alejano-Rodríguez, Pedro Barbero-Sacristán, María Barranco-Camino, Isabel Calvo-García, Concepción Diaz-Calera, Yasmin Drak-Hernández, JuanCarlos Fuentes-Barona, Leticia Galtier-Gómez, Esperanza Gómez-Fernández, Vera González-García, Rocío Horcajada-Alocén, Isabel Hortelano-Galán, Pilar Muñoz-Molina, Belén NavarroCarnero, Francisco C Pérez Sánchez, Isabel Sáenz-García-Baquero, Vicente I Torralba-Garrido, Francisco J Zufia-Garcia.

Hospital Clínico San Carlos: Andrea Valcarcel-Alonso.

\section{Authors' contributions}

Conception and design of manuscript: ERB, SMH, RMG and JALR. Data collec tion coordination: VGG and PMM. Data collection: COVID-AP Group. Analysis and interpretation: ERB and JALR. All authors and the group participated in the writing, review and final approval of the manuscript.

\section{Funding}

The study has not received funding, but the Foundation for Biomedical Research and Innovation in Primary Care (FIIBAP) will help with the costs of publication.

\section{Availability of data and materials}

The datasets used and/or analysed during the current study are available from the corresponding author on reasonable request.

Regarding data exchange, the Ethics Committee approved this research without considering the option of data sharing. The data contains sensitive clinical information about the patient, so there are ethical and legal restrictions to sharing the data set. The data are part of the COVID-AP study and can be requested by contacting the Ethics Committee at the email address ceic. hcsc@salud.madrid.org; or you can also contact the Primary Care Management of Madrid through the Technical Direction of Teaching and Research 
at the email address dtdei@salud.madrid.org. The COVID-AP Group may establish future collaborations with other groups based on the same data. The main researchers of the project will be contacted (Juan A López-Rodríguez at juanantonio.lopez@salud.madrid.org and info@covidap.es).However, each new project based on these data must be previously submitted to CEIC for approval.

\section{Declarations}

\section{Ethics approval and consent to participate}

This study was evaluated and approved from the Hospital Clínico San Carlos Ethical Committee 20/307- E COVID, and also had the approval from the Madrid Centro Local Investigation Commission (Project code: 12/20-C). Informed consent was obtained from all the participants.

\section{Consent for publication}

All the authors consent to the publication of this article by BMC Family Practice.

\section{Competing interests}

The authors declare that they have no competing interests.

\section{Author details}

${ }^{1}$ Primary Health Care Centre General Ricardos, Calle General Ricardos 131, 28019 Madrid, Spain. ${ }^{2}$ Health Services Research On Chronic Patients Network (REDISSEC), Madrid, Spain. ${ }^{3}$ Primary Health Care Centre Los Rosales, Madrid, Spain. ${ }^{4}$ Medical Specialties and Public Health Department, School of Health Sciences, University Rey Juan Carlos Alcorcón, Madrid, Spain. ${ }^{5}$ Research Support Unit, Primary Care Management, Madrid, Spain. ${ }^{6}$ Hospital Clínico San Carlos, Madrid, Spain.

Received: 31 October 2020 Accepted: 17 March 2021

Published online: 08 April 2021

\section{References}

1. N Zhu D Zhang W Wang X Li B Yang J Song2020 A novel coronavirus from patients with pneumonia in China, 2019 N Engl J Med. 38272733

2. Situación de COVID-19 en España. cnecovid. ISCIII. 2020. https://cneco vid.isciii.es/covid19/. Accessed 21 June 2020.

3. Ministerio de Sanidad E. Ministerio de Sanidad, Consumo y Bienestar Social - Profesionales - Situación actual Coronavirus. 2020. https:// www.mscbs.gob.es/profesionales/saludPublica/ccayes/alertasActual/ nCov-China/situacionActual.htm. Accessed 7 July 2020.

4. M Pollán B Pérez-Gómez R Pastor-Barriuso J Oteo MA Hernán M Pérez-Olmeda2020 Prevalence of SARS-CoV-2 in Spain (ENE-COVID): a nationwide, population-based seroepidemiological study Lancet. 6736 111 https://doi.org/10.1016/S0140-6736(20)31483-5

5. ZWu JM McGoogan 2020 Characteristics of and Important Lessons from the Coronavirus Disease 2019 (COVID-19) Outbreak in China: Summary of a Report of 72314 Cases from the Chinese Center for Disease Control and Prevention JAMA - Journal of the American Medical Association. 323123942

6. SRichardson JS Hirsch M Narasimhan JM Crawford T McGinn KW Davidson2020 Presenting Characteristics, Comorbidities, and Outcomes among 5700 Patients Hospitalized with COVID-19 in the New York City Area JAMA - J Am Med Assoc. 32320529

7. Goyal P, Choi JJ, Pinheiro LC, Schenck EJ, Chen R, Jabri A, et al. Clinical characteristics of Covid-19 in New York City. N Engl J Med. 2020;382:2372-4. https://doi.org/10.1056/NEJMc2010419.

8. de Lusignan S, Dorward J, Correa A, Jones N, Akinyemi O, Amirthalingam G, et al. Risk factors for SARS-CoV-2 among patients in the Oxford Royal College of General Practitioners Research and Surveillance
Centre primary care network: a cross-sectional study. Lancet Infect Dis. 2020;3099. doi:https://doi.org/10.1016/S1473-3099(20)30371-6.

9. Epidemiológica RN de V. Análisis de los casos de COVID-19 notificados a la RENAVE Informe COVID-19 n 33. 29 de mayo de 2020. Isciii. 2020;:11. https://www.isciii.es/QueHacemos/Servicios/VigilanciaSaludPublicaRENAVE/EnfermedadesTransmisibles/Documents/INFORMES/ InformesCOVID-19/Informe no 33. Análisis de los casos de COVID-19 hasta el 10 de mayo en España a 29 de mayo de 2020.pdf.

10. Gerencia Asistencial de Atención Primaria. Servicio Madrileño de Salud. Informe Técnico COVID-19 Atención Primaria Marzo-Abril 2020. 2020. Available at https://isanidad.com/wp-content/uploads/2020/06/Infor me-COVID-19-AP-Madrid.pdf. Accessed 4 Feb 2021

11. Ministerio de Sanidad E. Documento técnico Manejo en atención primaria y domiciliaria del. 2020;1-18. https://www.mscbs.gob.es/ profesionales/saludPublica/ccayes/alertasActual/nCov/documentos/ Manejo_primaria.pdf. Accessed 4 Feb 2021.

12. Comunidad de Madrid. COVID-19. Reorganización de la asistencia. Comunicados | Comunidad de Madrid. 2020. https://www.comunidad. madrid/servicios/salud/covid-19-reorganizacion-asistencia-comun icados\#reorganizacion-asistencial. Accessed 21 June 2020.

13. Zhu J, Ji P, Pang J, Zhong Z, Li H, He C, et al. Clinical characteristics of 3,062 COVID-19 patients: a meta-analysis. J Med Virol. 2020;92:1902-14. https://doi.org/10.1002/jmv.25884.

14. F Zhou T Yu R Du G Fan Y Liu Z Liu2020 Clinical course and risk factors for mortality of adult inpatients with COVID-19 in Wuhan, China: a retrospective cohort study Lancet. 395105462 https://doi.org/10.1016/ S0140-6736(20)30566-3

15. G Suleyman RA Fadel KM Malette C Hammond H Abdulla A Entz2020 Clinical Characteristics and Morbidity Associated With Coronavirus Disease 2019 in a Series of Patients in Metropolitan Detroit JAMA Netw open. 3 e2012270 https://doi.org/10.1001/jamanetworkopen.2020. 12270

16. Tenforde MW, Rose EB, Lindsell CJ, et al. Characteristics of adult outpatients and inpatients with COVID-19 - 11 Academic Medical Centers, United States, March-May 2020. MMWR Morb Mortal Wkly Rep. 2020;69:841-6. https://doi.org/10.15585/mmwr.mm6926e3.

17. Xianxian Zhao, Bili Zhang, Pan Li, Chaoqun Ma, Jiawei Gu, Pan Hou, Zhifu Guo, Hong Wu YB. Incidence, clinical characteristics and prog nostic factor of patients with COVID-19: a systematic review and metaanalysis. bmj yale. 2020. doi:https://doi.org/10.1101/2020.03.17.20037 572.

18. Tong JY, Wong A, Zhu D, Fastenberg JH, Tham T. The prevalence of olfactory and gustatory dysfunction in COVID-19 patients: a systematic review and meta-analysis. Otolaryngol Head Neck Surg. 2020;163(1):3-11. https://doi.org/10.1177/0194599820926473.

19. E Mehraeen F Behnezhad MA Salehi T Noori H Harandi SA SeyedAlinaghi 2020 Olfactory and gustatory dysfunctions due to the coronavirus disease (COVID-19): a review of current evidence Eur Arch Oto-Rhino-Laryngology. https://doi.org/10.1007/s00405-020-06120-6

20. Centro de coordinación de alertas y emergencias sanitarias. Actualización n 156. Enfermedad por el coronavirus (COVID-19). 06.07.2020. Situación de España. 2020;:1-12.

21. M Marshall A Howe G Howsam M Mulholland J Leach 2020 COVID-19: a danger and an opportunity for the future of general practice $\mathrm{Br} J \mathrm{Gen}$ Pract. 702701

22. Greenhalgh T, Koh GCH, Car J. Covid-19: A remote assessment in primary care. BMJ. 2020;368. doi:https://doi.org/10.1136/bmj.m1182.

23. Salisbury H. Helen salisbury: fear in the time of covid. BMJ. 2020;368:m1286. https://doi.org/10.1136/bmj.m1286.

24. Kidd M. Australia's primary care COVID-19 response. Aust J Gen Pract. 2020;49(Suppl 2). https://doi.org/10.31128/AJGP-COVID-02.

25. Thornton J. Covid-19: how coronavirus will change the face of general practice forever. BMJ. 2020;368:m1279. https://doi.org/10.1136/bmj. m1279.

26. C Llor A Moragas 2020 Coronavirus and primary care Atencion Primaria. 522946 
27. X Li HM Krumholz W Yip KK Cheng J Maeseneer De Q Meng2020 Quality of primary health care in China: challenges and recommendations Lancet. 395180212

28. V Verhoeven G Tsakitzidis H Philips P Royen Van 2020 Impact of the COVID-19 pandemic on the core functions of primary care: will the cure be worse than the disease? A qualitative interview study in Flemish GPs BMJ Open. 10 e039674 https://doi.org/10.1136/bmjop en-2020-039674

\section{Publisher's note}

Springer Nature remains neutral with regard to jurisdictional claims in published maps and institutional affiliations.
Ready to submit your research? Choose BMC and benefit from:

- fast, convenient online submission

- thorough peer review by experienced researchers in your field

- rapid publication on acceptance

- support for research data, including large and complex data types

- gold Open Access which fosters wider collaboration and increased citations

- maximum visibility for your research: over 100M website views per year

At BMC, research is always in progress.

Learn more biomedcentral.com/submissions 